\title{
The effect of fishmeal supplementation of a straw-based diet on growth and calorimetric efficiency of growth in heifers
}

\author{
BY ISABELLE ORTIGUES ${ }^{1 *}$, T. SMITH $H^{1} \uparrow$, M. GILL $L^{2}+$, S. B. CAMMELL \\ AND N.W. YARROW' \\ ${ }^{1} A F R C$ Institute for Grassland and Animal Production, Shinfield, Reading, Berkshire RG2 $9 A Q$ and \\ ${ }^{2}$ AFRC Institute for Grassland and Animal Production, Hurley, Maidenhead, Berkshire SL6 5LR
}

(Received 30 November 1989 - Accepted 24 April 1990)

Thirty-two $160 \mathrm{~kg}$ dairy heifers were used to measure the effects of increasing dietary protein content on growth and heat production. A basal diet containing $(\mathrm{g} / \mathrm{kg}) 550$ sodium hydroxide-treated straw, 220 barley, 220 sugarbeet pulp and 10 urea was offered with 0,76 and $152 \mathrm{~g}$ fishmeal/kg dry matter of the basal diet (F0, F1 and F2 levels respectively). The three diets were each given at two levels of feeding (low, L; high, H): $57.6 \mathrm{~g} / \mathrm{d}$ per $\mathrm{kg}$ metabolic body-weight $\left(\mathrm{W}^{0.75}\right)$ for the $\mathrm{LFO}$ diet and $74.7 \mathrm{~g} / \mathrm{d}$ per $\mathrm{kg} \mathrm{W}^{075}$ for the HFO diet. Apparent digestibility of the diets increased in response to the addition of fishmeal. Mean dry matter digestibility values were $0.67,0.67,0.69,0.66,0.68$ and 0.69 and those for acid-detergent fibre digestibility were $0 \cdot 60,0.63,0.66,0.58,0.60$ and 0.65 for diets LF0, LF1, LF2, HF0, HF1 and HF2 respectively. Nitrogen retention increased in response to both fishmeal and feeding level. Live-weight gains were 170, 296, $434 \mathrm{~g} / \mathrm{d}$ for the LFO, LF1 and LF2 diets and 468, 651 and $710 \mathrm{~g} / \mathrm{d}$ for the HFo, HF1 and HF2 diets respectively. There were significant effects of increasing the plane of feeding and the level of fishmeal in the diet on live-weight gain. Dietary effects on live-weight gains were accompanied by increases in mean energy retention of $23,45,82,94,160$ and $152 \mathrm{~kJ} / \mathrm{d}$ per $\mathrm{kg} \mathrm{W}^{0.75}$ for diets LF0, LF1, LF2, HF0, HF1 and HF2 respectively, but no definite evidence was obtained that dietary supplementation with fishmeal modified the efficiency of utilization of metabolizable energy for growth.

Fishmeal: Straw : Energy utilization: Growth: Heifer

Increased growth in cattle in response to fishmeal supplementation has been recorded and responses are consistently larger than those obtained with more degradable nitrogen supplements (Smith et al. $1980 a, b$; Oldham \& Smith, 1981). The magnitude of the response to fishmeal, however, depends on the quality of the basal diet. Thus, with high-concentrate diets (Smith et al. $1980 \mathrm{~b}$ ) or with high-quality forage diets supplemented with concentrate (Steen, 1985), the responses obtained have been small. On the other hand, with a poorerquality forage (straw), a marked increase in the weight gain of cattle was noted with a small increment of fishmeal, but a second increment did not elicit any further significant response, even though the highest live-weight gains remained lower than $700 \mathrm{~g} / \mathrm{d}$ (Smith et al. 1980a). Presumably in this latter case, growth was limited by the availability of energy.

The efficiency with which energy is utilized for growth is known to be low on forage diets (Agricultural Research Council, 1980), but the results discussed previously suggest that efficiency can be modified by manipulating the balance between absorbed nutrients. One such manipulation is to increase the supply of amino acids to the tissues through supplementation with undegradable protein.

The specific objective of the experiment reported here was, therefore, to determine

Present addresses: *INRA - CRZV Theix, 63122 Ceyrat, France.

$\dagger$ Grassland Research Station, Marondera, Zimbabwe.

‡ ODNRI, Central Avenue, Chatham Maritime, Chatham, Kent ME4 4TB. 
simultaneously the effect of different levels of fishmeal supplementation on diet digestibility, live-weight gain and the calorimetric efficiency of this gain $\left(k_{f}\right)$. A straw-based diet was offered to growing heifers at two planes of feeding, either alone or supplemented with two different levels of fishmeal. Preliminary results of this work have been presented (Ortigues et al. 1988).

\section{MATERIALS AND METHODS}

\section{Experimental plan}

The feeding trial lasted $104 \mathrm{~d}$ and for the major part of this time, the heifers were housed at the Institute of Grassland and Animal Production's (IGAP) Shinfield facility, in yards, with four animals per yard and with animals being yoked for individual feeding, as described by Smith et al. (1980 b). However, after a minimum of $10 \mathrm{~d}$ of adaptation to diet, groups of heifers (four at a time) from the main trial were taken to digestion standings where they remained for $7 \mathrm{~d}$ for measurement of diet digestibility and $\mathrm{N}$ retention. Thereafter, animals were transported to IGAP's Hurley facility for 2 weeks for measurement of the exchange of respiratory gases by open-circuit calorimetry. Heifers were then brought back to the main yard, where they remained, until completion of the experiment.

\section{Feeds and feeding}

The composition of feed constituents offered is presented in Table 1. Chopped winter barley straw was treated with $4.5 \mathrm{~g}$ sodium hydroxide $/ 100 \mathrm{~g}$ fresh straw, using a sodium hydroxide solution $(280 \mathrm{~g} / \mathrm{l})$. The unmolassed sugarbeet pulp was purchased from British Sugar plc and the fishmeal (Provimi $66^{\circledR}$ ) from British White Fishmeal Ltd. A mineral supplement (40 $\mathrm{g}$ Super Mindif ${ }^{\circledR}$ ) was added to each ration daily.

The basal diet consisted of straw, barley, sugarbeet pulp, and a urea-sulphur $(95 \cdot 5: 4 \cdot 5$, $\mathrm{w} / \mathrm{w}$ ) mixture in the following proportions $54 \cdot 7: 21 \cdot 7: 22 \cdot 6: 1 \cdot 0$ (by wt, dry matter (DM) basis). Treatment diets differed in the amounts of fishmeal added to the straw-rich basal diet. Levels of fishmeal addition were 0 (F0 diet), 76 (F1) and 152 (F2) g fishmeal DM/kg basal diet DM. These three diets were offered to the animals at two planes of feeding in a $2 \times 3$ factorial design. The planes of feeding were calculated for the F0 diet to supply $1 \cdot 1$ and 1.5 times the estimated (from Agricultural Research Council, 1980) maintenance requirements at $160 \mathrm{~kg}$ initial live weight for the low $(\mathrm{L})$ and high $(\mathrm{H})$ levels of feeding respectively. The amounts of feed offered to each animal were calculated on the basis of individual metabolic live weights $\left(\mathrm{W}^{0.75}\right)$. Allowances were adjusted weekly using the average of weekly weighings. In case of weight loss from one week to the next, feed allowances were kept unchanged for the following week. The feeds were offered in two equal daily meals, $7 \mathrm{~h}$ apart.

Fasting heat production (FHP) was measured on two extra heifers, which were maintained on the F1 diet (low fishmeal), at a daily DM allowance of $71.44 \mathrm{~g} / \mathrm{kg} \mathrm{W}^{0.75}$. Before measurements, the level of feeding was reduced to maintenance over $5 \mathrm{~d}$ and kept at maintenance for $7 \mathrm{~d}$. Feeds were then withdrawn for $90 \mathrm{~h}$; water was available at all times. Realimentation was done progressively.

\section{Animals}

Thirty-two heifers, aged from 4 to 6 months, and averaging 160 (SEM 1.1) kg initial live weight were used in the experiment. Two were selected on the basis of live weight (one heavy and one light) for measurement of FHP, while the remainder were blocked by weight on the basis of three previous weighings and randomized across six treatment groups with five animals per treatment. The succession of animals through the various measurements 
was based on the randomization of an incomplete block design (Cochran \& Cox, 1957) to allow for the constraint that only four measurements of digestibility and two of respiratory exchange could be made simultaneously.

\section{Measurements}

Intake. Feeds were sampled twice weekly for DM determination at $50^{\circ}$ for $48 \mathrm{~h}$. Separate samples were taken each time the rations were weighed out and bulked on a weekly basis. They were then ground through a $1 \mathrm{~mm}$ screen to be analysed for ash, total $\mathrm{N}$, aciddetergent fibre (ADF) and gross energy (GE). Refusals were collected daily and were either bulked weekly for the feeding trial, bulked over $5 \mathrm{~d}$ but $1 \mathrm{~d}$ in advance of the faecal and urine collection, or kept as individual samples during the calorimetric measurements. All refusals were dried $\left(50^{\circ}, 48 \mathrm{~h}\right)$, ground through a $1 \mathrm{~mm}$ screen and analysed for ash, total $\mathrm{N}$ and $\mathrm{ADF}$.

Live weight. All yarded animals were weighed twice weekly, $3 \cdot 5 \mathrm{~h}$ after the morning meal. They were also weighed at the end of the balance trial and on the first and last days of calorimetric measurements. Gut fill was estimated from a shrunk body-weight taken on day 105 after 25 and $12 \mathrm{~h}$ withdrawal of food and water respectively.

Rumen fluid and blood samples. Rumen fluid was sampled with a tracheal tube 2.5 and $7 \mathrm{~h}$ postprandially on days 97 and 98 of the experiment; $\mathrm{pH}$ was determined immediately and subsamples were stored at $-20^{\circ}$ for volatile fatty acid (VFA) analysis. Ammonia-N concentrations were determined on the $2.5 \mathrm{~h}$ postprandial samples only, after acidification with a few drops of concentrated sulphuric acid.

Blood was sampled also on days 97 and 98 , by jugular puncture $4 \mathrm{~h}$ postprandially using EDTA-K $\mathrm{K}_{2}$ as anticoagulant, centrifuged and stored at $-20^{\circ}$ for analysis of plasma urea-N, glucose and non-esterified fatty acids (NEFA).

Faeces and urine collection. After a minimum of $10 \mathrm{~d}$ adaptation to the diets, heifers were moved, in groups of four animals, to digestion standings, for a $5 \mathrm{~d}$ total collection of faeces and urine after a 2 d adaptation to the standings (Smith, 1979). Faeces were weighed daily and two subsamples were taken, one $(30 \mathrm{~g} / \mathrm{kg})$ to be preserved in sulphuric acid $(1.5 \mathrm{M})$ for $\mathrm{N}$ determination and the other one $(50 \mathrm{~g} / \mathrm{kg})$ to be dried at $50^{\circ}$ for $48 \mathrm{~h}$ and ground through a $1 \mathrm{~mm}$ screen for DM, ash, ADF and GE analysis. Subsamples were bulked on a $5 \mathrm{~d}$ basis.

Attempts to separate urine and faeces by the introduction and maintenance of urinary catheters proved unsuccessful in these young heifers, and hence for $15 \mathrm{~h}$ daily the urine was left to drain down slanted metal trays ('contaminated urine'). During the remaining $9 \mathrm{~h}$, urine was collected manually, directly on urination to obtain a 'pure sample'. Both types of samples were collected in a $2 \mathrm{M}_{2} \mathrm{H}_{2} \mathrm{SO}_{4}$ solution and bulked over the $5 \mathrm{~d}$. Both urine samples served to give a measure of total urine output, whereas $\mathrm{N}$ and GE urinary excretion was determined on the basis of the $\mathrm{N}$ and GE contents of the 'pure urine' samples only. Of the total urine output, 318 (SE 15.6) $\mathrm{ml} / \mathrm{l}$ was collected as 'pure urine'. This technique may partition $\mathrm{N}$ and $\mathrm{GE}$ excretion between faeces and urine slightly inaccurately but should not affect the results of $\mathrm{N}$ balance and energy retention.

Standings and metal trays were washed daily with tap water. Washings were collected, stored in $\mathrm{H}_{2} \mathrm{SO}_{4}(2 \mathrm{M})$, and analysed for $\mathrm{DM}$ and $\mathrm{N}$.

Indirect calorimetric measurement. Respiratory exchanges were measured on two animals at a time with each animal spending $3 \mathrm{~d}$ in one of the two calorimetry chambers, the measurements being made on the last $2 \mathrm{~d}$. Flow-rates and gaseous composition (oxygen, carbon dioxide, methane) of air flowing in and out of the chambers were measured as described by Cammell et al. (1981) with the modifications according to Cammell et al. (1986). A deadspace correction was made but never exceeded $1 \%$ of total gas production. Gravimetric calibration of the system showed an average recovery of $95.5 \%$ from one of 
the chambers. Results pertaining to this chamber were corrected correspondingly. FHP was measured in the middle of the experiment using the two additional heifers. Measurements were made for the last $24 \mathrm{~h}$ of a $90 \mathrm{~h}$ fast.

\section{Analytical methods}

Organic matter (OM) content of the samples was determined by overnight ashing at $550^{\circ}$. ADF was analysed according to Van Soest (1963) after removal of starch as described by Terry \& Outen (1973) for the samples which contained starch. GE of all samples was measured in an adiabatic bomb calorimeter. Before this analysis, urine samples were neutralized with $\mathrm{NaOH}$ to a $\mathrm{pH}$ of $7.5-8.5$ followed by freeze-drying. Rumen fluid VFA were analysed by gas-liquid chromatography (Sutton \& Johnson, 1969) with isocaproic acid as internal standard. Automated methods were used for rumen $\mathrm{NH}_{3}-\mathrm{N}$ (Technicon Instruments), plasma urea (Boehringer Mannheim), plasma glucose (Boehringer Mannheim) and plasma NEFA (Wako Chemicals).

\section{Calculations}

Heat production was calculated according to Brouwer (1965) from the observed values for $\mathrm{CH}_{4}, \mathrm{O}_{2}$ and $\mathrm{CO}_{2}$ exchange and from the urinary $\mathrm{N}$ excretion calculated from the intakes measured on the days of respiratory exchange measurements for each animal and the previously measured proportion of $\mathrm{N}$ excreted in the urine.

Efficiency of metabolizable energy (ME) utilization for growth $\left(k_{f}\right)$ at each level of fishmeal was obtained from two methods of analysis. Relationships were fitted between ME intake (MEI) and retained energy (RE) both scaled on the basis of $\mathrm{W}^{0.75}$ according to both a linear regression line and the exponential Mitscherlich equation as described by Cammell et al. (1986):

$$
\mathrm{RE}(\mathrm{MJ} / \mathrm{d})=\mathrm{P} 3(1-\exp (-\mathrm{P} 1(\mathrm{MEI}-\mathrm{P} 2))),
$$

where $\mathrm{P} 1$ is the curvature (rate of decrease in efficiency of energy retention with increasing MEI), P2 the estimated ME requirements for maintenance and P3 the asymptote (maximum potential energy retention). At any particular level of MEI, the efficiency of ME utilization $\left(k_{f}\right)$ can be obtained by differentiation of equation 1 with respect to MEI thus:

$$
k_{f}=\mathrm{P} 1 \mathrm{P} 3 \exp (-\mathrm{P} 1(\mathrm{MEI}-\mathrm{P} 2)) \text {. }
$$

\section{Statistical analysis}

Data were analysed according to a randomized block design with a $2 \times 3$ factorial arrangement of treatments (two planes of feeding $\times$ three levels of fishmeal). The linear and quadratic trends of the effects of fishmeal supplements were tested statistically. Missing values due to the unexplained death of one animal and a large refusal during calorimetry were estimated using the GENSTAT computer package and degrees of freedom were modified as appropriate. As the gaseous exchange and derived criteria were calculated separately for each day of measurement (two per animal), all relevant data were analysed according to a split plot design using days as subplots. Parameters derived from the exponential equation were compared by the Student's $t$ test.

\section{RESULTS}

\section{Feed composition and intake}

The chemical composition of the diet constituents and the average daily intakes for each treatment, expressed on a $W^{0.75}$ basis, are presented in Tables 1 and 2 . Within each plane of feeding, the intake of the basal diet (F0) remained similar across treatment groups as 
Table 1. Chemical composition (dry matter basis) of individual feedstuffs and daily amounts of individual feedstuffs offered in each diet ( $\mathrm{g}$ dry matter $/ \mathrm{kg}$ metabolic live weight $\left(W^{\mathbf{0} 75}\right)$ )

\begin{tabular}{|c|c|c|c|c|c|}
\hline & $\begin{array}{l}\text { Sodium hydroxide- } \\
\text { treated straw }\end{array}$ & Barley & $\begin{array}{l}\text { Sugarbeet } \\
\text { pulp }\end{array}$ & Fishmeal & Urea \\
\hline \multicolumn{6}{|l|}{ Chemical composition } \\
\hline Organic matter $(\mathrm{g} / \mathrm{kg})$ & 879 & 974 & 900 & 802 & ND \\
\hline Acid-detergent fibre $(\mathrm{g} / \mathrm{kg})$ & 504 & 91 & 174 & 36 & ND \\
\hline Gross energy $(\mathrm{MJ} / \mathrm{kg})$ & $17 \cdot 26$ & $18 \cdot 48$ & $16 \cdot 51$ & $20 \cdot 13$ & ND \\
\hline Nitrogen $(\mathrm{g} / \mathrm{kg})$ & $7 \cdot 4$ & $21 \cdot 5$ & $16 \cdot 7$ & 113 & ND \\
\hline \multicolumn{6}{|l|}{ Diet } \\
\hline LF0 & $30 \cdot 6$ & $12 \cdot 9$ & $12 \cdot 9$ & 0 & 0.6 \\
\hline $\mathrm{LFl}$ & $30 \cdot 6$ & $12 \cdot 9$ & $12 \cdot 9$ & $4 \cdot 4$ & 0.6 \\
\hline $\mathrm{LF} 2$ & 30.6 & $12 \cdot 9$ & $12 \cdot 9$ & $8 \cdot 8$ & 0.6 \\
\hline $\mathrm{HF} 0$ & $40 \cdot 0$ & $17 \cdot 3$ & $17 \cdot 3$ & 0 & 0.7 \\
\hline HF 1 & $40 \cdot 0$ & $17 \cdot 3$ & $17 \cdot 3$ & $6 \cdot 0$ & 0.7 \\
\hline $\mathrm{HF} 2$ & 400 & $17 \cdot 3$ & $17 \cdot 3$ & 120 & 0.7 \\
\hline
\end{tabular}

ND, not determined; F0, F1, F2 - 0, 76 and $152 \mathrm{~g}$ fishmeal DM $/ \mathrm{kg}$ respectively; $\mathrm{L}, \mathrm{H}-$ low and high levels of feeding respectively.

Table 2. Average intakes ( $\mathrm{g} / \mathrm{d}$ per $\mathrm{kg}$ metabolic live weight $\left(W^{0.75}\right)$ )of heifers offered strawbased diets at two planes of feeding and supplemented with different levels of fishmeal

\begin{tabular}{|c|c|c|c|c|c|}
\hline Diet & $\begin{array}{c}\text { Dry } \\
\text { matter } \\
\text { (g/kg W0.75 } \\
\text { per d) }\end{array}$ & $\begin{array}{l}\text { Organic } \\
\text { matter } \\
\text { (g/kg W0.75 } \\
\text { per d) }\end{array}$ & $\begin{array}{c}\text { Acid- } \\
\text { detergent } \\
\text { fibre } \\
\left(\mathrm{g} / \mathrm{kg} \mathrm{W}^{0-75}\right. \\
\text { per } \mathrm{d})\end{array}$ & 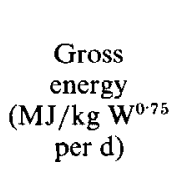 & $\begin{array}{l}\text { Nitrogen } \\
\left(\mathrm{g} / \mathrm{kg} \mathrm{W^{0.75 }}\right. \\
\text { per d) }\end{array}$ \\
\hline LF0 & 57.6 & $52 \cdot 1$ & 19.1 & 0.990 & 0.964 \\
\hline LF I & 61.6 & $55 \cdot 3$ & $19 \cdot 0$ & 1.072 & 1.456 \\
\hline LF2 & $65 \cdot 7$ & $58 \cdot 6$ & $19 \cdot 1$ & $1 \cdot 156$ & 1.936 \\
\hline $\mathrm{HFO}$ & $74 \cdot 7$ & $67 \cdot 9$ & $24 \cdot 6$ & $1 \cdot 287$ & 1.263 \\
\hline $\mathrm{HF} 1$ & $80 \cdot 5$ & $72 \cdot 4$ & $24 \cdot 7$ & 1.406 & 1.917 \\
\hline $\mathrm{HF} 2$ & $85 \cdot 5$ & $76 \cdot 4$ & $25 \cdot 0$ & $1 \cdot 505$ & 2.536 \\
\hline SEM† & 0.40 & 0.32 & 0.15 & 0.0090 & 0.0140 \\
\hline $\begin{array}{l}\text { Statistical significance of treatment } \\
\text { effects }\end{array}$ & $\mathrm{PF} \times \mathrm{F}(1)^{* * *}$ & $\mathrm{PF} \times \mathrm{F}(\mathrm{l})^{* * *}$ & $\mathrm{PF}^{* * *}$ & $P F \times F(1)^{* * *}$ & $\mathrm{PF} \times \mathrm{F}(1)^{* * *}$ \\
\hline
\end{tabular}

$\mathrm{PF}$, effect of the plane of feeding; $\mathrm{F}(1)$, linear effect of fishmeal; PF $\times F$, interaction term; F0, F1, F2 - 0, 76 and $152 \mathrm{~g}$ fishmeal $\mathrm{DM} / \mathrm{kg}$ respectively; $\mathrm{L}, \mathrm{H}$ - low and high planes of feeding respectively.

*** $P<0 \cdot 01$.

$\dagger$ Standard error of treatment means.

indicated by the relatively constant intakes of ADF. Therefore, as planned, differences in $\mathrm{DM}$ and $\mathrm{N}$ intake within feeding level $(\mathrm{L}$ and $\mathrm{H})$ could be attributed mostly to the addition of fishmeal to the diets.

\section{Rumen and blood variables}

Rumen fermentation pattern was little influenced by dietary treatments, as indicated by the lack of variation in the (acetate $+\mathbf{n}$-butyrate): propionate ratio (Table 3 ). Fishmeal supplementation increased rumen $\mathrm{NH}_{3}-\mathrm{N}$ concentration linearly with no apparent effect of plane of feeding. Parallel changes in plasma urea concentrations were also observed (Table 3).

On the low plane of feeding, plasma glucose concentrations were increased at the high 
Table 3. Average rumen volatile fatty acid (VFA) concentrations ( $m M)$ and molar proportions, molar ratios, acetate $+n$-butyrate:propionate, and average concentrations of rumen ammonia-nitrogen (mM), plasma urea, glucose and non-esterified fatty acids $(\mathrm{mm})$ in heifers offered straw-based diets at two planes of feeding and supplemented with different levels of fishmeal

\begin{tabular}{|c|c|c|c|c|c|c|c|c|}
\hline Diet... & LF0 & LF 1 & LF2 & HF0 & HF1 & $\mathrm{HF} 2$ & SEM $\dagger$ & $\begin{array}{c}\text { Statistical } \\
\text { significance } \\
\text { of treatment } \\
\text { effects }\end{array}$ \\
\hline $\begin{array}{l}\text { Total VFA } \\
\text { concentrations }\end{array}$ & $78 \cdot 0$ & $89 \cdot 5$ & $85 \cdot 5$ & $71 \cdot 0$ & $92 \cdot 0$ & $79 \cdot 4$ & 7.88 & - \\
\hline \multicolumn{9}{|l|}{ VFA molar proportions } \\
\hline Acetate & 0.722 & 0.718 & $0 \cdot 715$ & 0.724 & $0 \cdot 728$ & 0.718 & 0.0064 & $\ldots$ \\
\hline Propionate & $0 \cdot 178$ & $0 \cdot 171$ & $0 \cdot 164$ & $0 \cdot 184$ & $0 \cdot 170$ & $0 \cdot 177$ & 0.0057 & - \\
\hline$n$-butyrate & 0.080 & 0.089 & $0 \cdot 098$ & 0.071 & 0.082 & 0.084 & 0.0052 & $\mathrm{PF}^{* *}, \mathrm{~F}(1)^{* * *}$ \\
\hline $\begin{array}{l}\text { Acetate }+n \text {-butyrate: } \\
\text { propionate }\end{array}$ & $4 \cdot 6$ & $4 \cdot 8$ & $5 \cdot 0$ & $4 \cdot 3$ & $4 \cdot 8$ & $4 \cdot 5$ & $0 \cdot 17$ & \\
\hline Rumen $\mathrm{NH}_{3}-\mathrm{N}$ & $4 \cdot 53$ & $8 \cdot 81$ & $12 \cdot 39$ & $4 \cdot 72$ & $10 \cdot 11$ & $13 \cdot 35$ & 0.644 & $\mathrm{~F}(1)^{* * *}$ \\
\hline Plasma urea & $3 \cdot 28$ & $4 \cdot 77$ & $5 \cdot 92$ & $2 \cdot 55$ & $4 \cdot 60$ & $6 \cdot 23$ & $0 \cdot 268$ & $\mathrm{~F}(\mathrm{l})^{* * *}$ \\
\hline Plasma glucose & $4 \cdot 50$ & $4 \cdot 53$ & 489 & $4 \cdot 70$ & $5 \cdot 53$ & $5 \cdot 21$ & 0.121 & $\mathrm{PF} \times \mathrm{F}(\mathrm{q})^{* * *}$ \\
\hline $\begin{array}{l}\text { Plasma non-esterified } \\
\text { fatty acids }\end{array}$ & $93 \cdot 6$ & $87 \cdot 0$ & $109 \cdot 8$ & $97 \cdot 4$ & 113.4 & 113.4 & $12 \cdot 57$ & - \\
\hline
\end{tabular}

$P F$, effect of the plane of feeding; $F(1)$, linear effect of fishmeal; $F(q)$, quadratic effect of fishmeal; $P F \times F$, interaction term; F0, F1, F2 - 0,76 and $152 \mathrm{~g}$ fishmeal $\mathrm{DM} / \mathrm{Kg}$ respectively; $\mathrm{L}, \mathrm{H}-$ low and high planes of feeding respectively.

** $0.01<P<0.05, * * * P<0.01$.

$\dagger$ Standard error of treatment means.

fishmeal level only, whereas at the high plane of feeding glucose concentrations were significantly elevated only at the low fishmeal level (HF1). Plasma NEFA were not significantly affected by dietary treatment (Table 3).

\section{Apparent digestibility and $N$ balance}

Apparent digestibility of DM in the basal diet averaged 0.66 (Table 4). Fishmeal additions significantly increased DM digestibility of the whole diet but there were no significant effects of plane of feeding. ADF, GE and $\mathrm{N}$ digestibilities were all linearly increased by fishmeal supplementation, but there was little effect of elevating the plane of feeding. $\mathrm{N}$ balance was linearly increased by fishmeal addition to the diet, as well as by the increase in the plane of feeding.

\section{Animal performance}

The initial live weight of the heifers (Table 5) showed some statistically significant differences across treatments which were unexpected on the basis of the live weights used to create blocks. Blocking live weights, obtained the week before the actual start of the trial averaged 154 (SEM 3.1), 155 (SEM 2.5), 155 (SEM 3.0), 156 (SEM 2.7), 156 (SEM 2.8) and 155 (SEM $3.0) \mathrm{kg}$ for diets LF0, LF1, LF2 and HF0, HF1 and HF2 respectively. Adjustment of liveweight gain data using covariance analysis was investigated; however, it did not improve the responses measured and it was not used in the final analysis.

Live-weight gains, calculated by linear regression, were significantly higher at the higher plane of feeding ( $170 \mathrm{~g} / \mathrm{d}$ on LF0 and $468 \mathrm{~g} / \mathrm{d}$ on HF0) (Table 5). Addition of fishmeal to the diets had a positive linear effect $(P<0.01)$ on live-weight gains, although the second 
Table 4. Coefficients of apparent digestibility of dry matter, organic matter, acid-detergent fibre, gross energy and nitrogen and $N$ balance (in $\mathrm{g} / \mathrm{d}$ or $\mathrm{g} / \mathrm{kg} N$ intake per d) in heifers offered straw-based diets at two planes of feeding and supplemented with different levels of fishmeal

\begin{tabular}{|c|c|c|c|c|c|c|c|c|}
\hline Diet... & LF0 & LF1 & $\mathrm{LF} 2$ & HF0 & HF1 & $\mathrm{HF} 2$ & $\operatorname{SEM}^{\dagger}$ & $\begin{array}{c}\text { Statistical } \\
\text { significance } \\
\text { of treatment } \\
\text { effects }\end{array}$ \\
\hline \multicolumn{9}{|l|}{ Digestibility } \\
\hline Dry matter & 0.672 & 0.668 & 0.688 & 0.655 & $0 \cdot 682$ & 0.688 & $0 \cdot 0066$ & $\mathrm{~F}(\mathrm{l})^{* * *}$ \\
\hline Organic matter & $0 \cdot 689$ & $0 \cdot 694$ & 0.714 & 0.647 & 0.702 & $0 \cdot 710$ & $0 \cdot 0095$ & $P F \times F(1, q)^{* *}$ \\
\hline Acid-detergent fibre & 0.602 & 0.634 & 0.657 & 0.577 & $0-601$ & 0.653 & $0 \cdot 0176$ & $\mathrm{~F}(1)^{* * * *}$ \\
\hline Gross energy & 0.632 & 0.643 & 0.669 & 0.617 & 0.656 & 0.669 & $0 \cdot 0083$ & $\mathrm{~F}(\mathrm{l})^{* * *}$ \\
\hline $\mathrm{N}$ & 0.446 & 0.519 & 0.621 & 0.411 & 0.569 & 0.586 & 0.0196 & $\begin{array}{l}F(1)^{* * *} \\
P F \times F(q)^{*}\end{array}$ \\
\hline \multicolumn{9}{|l|}{$\mathrm{N}$ balance } \\
\hline$g / d$ & $3 \cdot 8$ & $10 \cdot 1$ & $17 \cdot 4$ & $11 \cdot 7$ & $24 \cdot 4$ & $33 \cdot 5$ & $1 \cdot 79$ & $\mathrm{~F}(1)^{* * *}, \mathrm{PF}^{* * *}$ \\
\hline $\mathrm{g} / \mathrm{kg} \mathrm{N}$ intake per $\mathrm{d}$ & 0.94 & 1.49 & 1.85 & $1 \cdot 81$ & $2 \cdot 51$ & $2 \cdot 60$ & 1.98 & $\mathrm{~F}(1)^{* * *}, \mathrm{PF}^{* * *}$ \\
\hline
\end{tabular}

$P F$, effect of the plane of feeding; $F(l)$, linear effect of fishmeal; $F(q)$, quadratic effect of fishmeal; $P F \times F$, interaction term; F0, F1, F2 - 0, 76 and $152 \mathrm{~g}$ fishmeal DM/ $\mathrm{kg}$ respectively; $\mathrm{L}, \mathrm{H}$ - low and high planes of feeding respectively.

$* 0.05<P<0.10$, ** $0.01<P<0.05, * * * P<0.01$.

$\dagger$ Standard error of treatment means.

Table 5. Initial and final live weights $(\mathrm{kg})$, live-weight gains $(\mathrm{g} / \mathrm{d})$, gut fill (as a proportion of final live weight) and body scores of heifers offered straw-based diets at two planes of feeding and supplemented with different levels of fishmeal

\begin{tabular}{|c|c|c|c|c|c|c|c|c|}
\hline Diets... & LF0 & LF1 & LF2 & $\mathrm{HFO}$ & $\mathrm{HFl}$ & HF2 & $\mathrm{SEM}_{\dagger}^{\dagger}$ & $\begin{array}{c}\text { Statistical } \\
\text { significance } \\
\text { of treatment } \\
\text { effects }\end{array}$ \\
\hline \multicolumn{9}{|l|}{ Live weight } \\
\hline Initial & 156 & 159 & 159 & 164 & 162 & 161 & $0 \cdot 8$ & $\mathrm{PF} \times \mathrm{F}(1)^{* * *}$ \\
\hline Final & 175 & 190 & 209 & 212 & 229 & 235 & $2 \cdot 7$ & $\mathrm{PF}^{* * *}, \mathrm{~F}(1)^{* * *}$ \\
\hline Live-weight gain & 170 & 296 & 434 & 468 & 651 & 710 & $29 \cdot 0$ & $\mathrm{PF}^{* * *}, \mathrm{~F}(\mathrm{l})^{* * *}$ \\
\hline Gut fill & 0.068 & 0.063 & $0 \cdot 071$ & $0 \cdot 073$ & 0.067 & 0.077 & 0.0069 & \\
\hline
\end{tabular}

$P F$, effect of the plane of feeding; $F(1)$, linear effect of fishmeal; $F(q)$, quadratic effect of fishmeal; $P F \times F$, interaction term; F0, F1, F2 - 0, 76 and $152 \mathrm{~g}$ fishmeal DM $/ \mathrm{kg}$ respectively; L, H - low and high planes of feeding respectively.

* $0.05<P<0.10$, ** $0.01<P<0.05$, *** $P<0.01$.

$\dagger$ Standard error of treatment means.

increment of fishmeal at the high plane of feeding (HF2 diet) appeared to elicit a smaller response than the first increment (HF1 diet). Results for the HF2 diet, however, were associated with a large standard error. Since gut fill represented a relatively constant proportion of live weight the differences in live-weight gain among treatment groups were not artefacts due to differences in gut fill (Table 5). 
Table 6. Mean live-weights of the animals over the balance period $(\mathrm{kg})$, gross energy intake and partition of energy utilization $\left(\mathrm{kJ} / \mathrm{d}\right.$ per $\mathrm{kg}$ metabolic live weight $\left.\left(\mathrm{W}^{0.75}\right)\right)$ during the measurements of respiratory exchanges in heifers offered straw-based diets at two planes of feeding and supplemented with different levels of fishmeal

\begin{tabular}{|c|c|c|c|c|c|c|c|c|}
\hline Diets... & LF0 & LF1 & $\mathrm{LF} 2$ & HF0 & $\mathrm{HFl}$ & HF2 & SEM $\dagger$ & $\begin{array}{c}\text { Statistical } \\
\text { significance } \\
\text { of treatment } \\
\text { effects }\end{array}$ \\
\hline Live weight & 161 & 169 & 178 & 189 & 188 & 193 & $3 \cdot 6$ & $\mathrm{PF}^{* * *}, \mathrm{~F}(\mathrm{l})^{* *}$ \\
\hline Gross energy intake & 1033 & 1116 & 1180 & 1343 & 1430 & 1481 & $24 \cdot 0$ & $\mathrm{PF}^{* * *}, \mathrm{~F}(\mathrm{l})^{* * *}$ \\
\hline \multicolumn{9}{|l|}{ Energy losses } \\
\hline Faeces & 382 & 398 & 390 & 505 & 493 & 491 & $14 \cdot 3$ & $\mathrm{PF}^{* * *}$ \\
\hline Urine & 24 & 30 & 36 & 24 & 32 & 36 & 1.6 & $\mathrm{~F}(1)^{* * * *}$ \\
\hline Methane & 92 & 88 & 90 & 106 & 108 & 108 & $24 \cdot 5$ & $\mathrm{PF}^{* * *}$ \\
\hline Heat & 512 & 555 & 580 & 615 & 636 & 693 & $10 \cdot 3$ & $\mathrm{PF}^{* * *}, \mathrm{~F}(1)^{* * *}$ \\
\hline Energy retention & 23 & 45 & 82 & 94 & 160 & 152 & $13 \cdot 5$ & $\mathrm{PF}^{* * *}, \mathrm{~F}(\mathrm{l})^{* * *}$ \\
\hline
\end{tabular}

PF, effect of the plane of feeding; F(1), linear effect of fishmeal ; F(q), quadratic effect of fishmeal; F0, Fl, F2 0,76 and $152 \mathrm{~g}$ fishmeal $\mathrm{DM} / \mathrm{kg}$ respectively; $\mathrm{L}, \mathrm{H}$ - low and high planes of feeding respectively.

* $0.05<P<0.10, * * 0.01<P<0.05,{ }^{* * *} P<0.01$.

$\dagger$ Standard error of treatment means.

\section{Partition of energy intake}

The partition of GE intake as determined by calorimetry is presented in Table 6. Urinary energy represented $1.8-3.0 \%$ of the GE intake, as previously reported for straw diets (Robb et al. 1980). $\mathrm{CH}_{4}$ production by the heifers remained unchanged with fishmeal supplementation and could be considered to be a function of the level of feeding of the basal diet alone. Energy retention was significantly increased with both plane of feeding and fishmeal supplementation.

Metabolizability of the diets (ME:GE) was elevated at the high plane of feeding $(P<$ $0 \cdot 10)$ and increased linearly with fishmeal $(P<0.01)$. Values averaged $0.518,0.538,0.562$ and $0.527,0.557$ and 0.571 (SEM 0.0088) for diets LF0, LF1, LF2 and HF0, HF1 and HF2 respectively. Thus, ME intakes were 535, 600, 662, 709, 797 and 845 (SEM 16.7) $\mathrm{kJ} / \mathrm{d}$ per $\mathrm{kg} \mathrm{W}^{0 \cdot 75}$ for diets $\mathrm{LF} 0, \mathrm{LF} 1, \mathrm{LF} 2, \mathrm{HF} 0, \mathrm{HF} 1$ and HF2 respectively.

\section{FHP}

The FHP values were 19.49 and $17 \cdot 76 \mathrm{MJ} / \mathrm{d}$ for each of the two animals. These values corresponded to 0.392 and $0.357 \mathrm{MJ} / \mathrm{d}$ per $\mathrm{kg} \mathrm{W}^{0.75}$.

\section{Efficiency of $M E$ utilization for growth}

The calorimetric efficiencies of ME utilization for growth at each of the three levels of fishmeal were first examined by fitting linear regression lines to the data (Table 7). These linear relationships accounted for $76 \cdot 3,83.6$ and $59 \cdot 2 \%$ of the total variance for the F0, F1 and F2 diets respectively. Comparison of slopes showed that the efficiency of $\mathrm{ME}$ utilization for growth was increased $(P<0.05)$ by the first increment of fishmeal but was lower with the second increment of fishmeal to a value not significantly different from that of the basal diet (F0). From these relationships the $\mathrm{ME}$ requirements for maintenance were extrapolated to be higher with the F1 diet than with the F0 or F2 diets. However, the Agricultural Research Council (1980) definition of $k_{f}$ confines its derivation to energy retention values above maintenance. The two daily energy retention values for one heifer on treatment LF1 were markedly negative and when these were excluded from the 
Table 7. Equations relating energy retention and metabolizable energy (ME) intake (MEI) (both in $\mathrm{MJ} / \mathrm{kg}$ metabolic live weight $\left(W^{0.75}\right)$ per d) for heifers offered straw-based diets at two planes of feeding and supplemented with different levels of fishmeal

\begin{tabular}{|c|c|c|c|c|c|c|c|c|}
\hline \multirow{3}{*}{$\begin{array}{l}\text { Fishmeal level ... } \\
\qquad n^{*} \ldots\end{array}$} & \multirow{2}{*}{\multicolumn{2}{|c|}{$\begin{array}{c}\text { None } \\
8\end{array}$}} & \multicolumn{4}{|c|}{ Low } & \multirow{2}{*}{\multicolumn{2}{|c|}{$\frac{\text { High }}{10}$}} \\
\hline & & & \multicolumn{2}{|c|}{10} & \multicolumn{2}{|c|}{9} & & \\
\hline & Mean & $\mathrm{SE}$ & Mean & SE & Mean & SE & Mean & $\mathrm{SE}$ \\
\hline \multicolumn{9}{|l|}{ Linear regression } \\
\hline Slope & $0.413^{\mathrm{a}}$ & $0 \cdot 0588$ & $0.636^{\mathrm{b}}$ & 0.0644 & 0.525 & 0.0576 & $0.377^{\mathrm{a}}$ & 0.0705 \\
\hline Intercept & $-0.192^{\mathrm{a}}$ & 0.0369 & $-0.341^{b}$ & 0.0454 & $-0 \cdot 256$ & 0.0416 & $-0 \cdot 167^{a}$ & 0.0536 \\
\hline $\mathrm{ME}_{\mathrm{m}}$ & $0 \cdot 465$ & - & 0.536 & - & 0.488 & - & 0.443 & - \\
\hline$r^{m}$ & $0 \cdot 882$ & - & 0.919 & - & 0.916 & - & 0.783 & - \\
\hline RSD & 0.0210 & - & 0.0292 & - & 0.0224 & - & 0.0312 & - \\
\hline \multicolumn{9}{|l|}{ Curvilinear model } \\
\hline Pl & $1.591^{2}$ & 0.3939 & $0.285^{b}$ & 0.3154 & $0 \cdot 773$ & $0 \cdot 2588$ & $1 \cdot 308^{a}$ & 0.4098 \\
\hline $\mathrm{P} 2$ & $0.479^{a}$ & 0.0172 & $0.535^{\mathrm{b}}$ & 0.0780 & 0.501 & 0.0159 & $0.493^{\mathrm{ab}}$ & 0.0291 \\
\hline P3 & $0.328^{a}$ & 0.0996 & $2 \cdot 288^{u}$ & $2 \cdot 6299$ & 0.792 & 0.2858 & $0.413^{a}$ & 0.1413 \\
\hline \multicolumn{9}{|c|}{$\begin{array}{l}\text { Predicted efficiency } \\
\text { at MEI }\left(\mathrm{MJ} / \mathrm{kg} \mathrm{W}^{0 \cdot 75} \text { per } \mathrm{d}\right) \text { of: }\end{array}$} \\
\hline 0.5 & $0.504^{\mathrm{a}}$ & 0.0461 & $0.656^{\mathrm{b}}$ & 0.0302 & $0 \cdot 613$ & 0.0329 & $0.535^{\mathrm{a}}$ & 0.0406 \\
\hline 0.6 & $0 \cdot 430^{\mathrm{a}}$ & 0.0557 & $0.638^{\mathrm{b}}$ & 0.0470 & 0.567 & 0.0456 & $0.470^{\mathrm{a}}$ & 0.0548 \\
\hline 0.7 & $0 \cdot 367^{\mathrm{a}}$ & 0.0616 & $0.621^{\mathrm{b}}$ & 0.0631 & 0.525 & 0.0574 & $0.412^{\mathrm{a}}$ & 0.0651 \\
\hline $0 \cdot 8$ & $0 \cdot 313^{\mathrm{a}}$ & 0.0646 & $0.604^{b}$ & 0.0785 & 0.486 & 0.0675 & $0 \cdot 361^{a}$ & 0.0721 \\
\hline
\end{tabular}

$M E_{m}$, estimated $M E$ requirements for maintenance $\left(M J / \mathrm{kg} \mathrm{W}^{0.75}\right.$ per d); RSD, residual standard deviation; $P 1$, rate of decrease in $k_{f}$ with increasing $\mathrm{MEI}$; $\mathrm{P}$ 2, estimated $\mathrm{ME}$ requirements for maintenance; P3, maximum potential energy retention.

a.1) Mean values in the same horizontal row with different superscript letters were significantly different $(P<$ 0.05 ). When comparisons were made using $n 9$ for the low-fishmeal diet, differences were not significant.

* No. of animals per treatment; $n 9$ for the low-fishmeal diet corresponds to the removal of one heifer that presented a negative energy balance.

analysis, the efficiency value for F1 decreased to 0.525 (Table 7), although the percentage of the variation accounted for was little changed $(82.8 \%$ compared to $83.6 \%)$. The efficiency value for $\mathrm{F} 1$ no longer differed from that for F0 or F2.

The exponential model was then fitted to the data for each level of fishmeal using the two measured values of FHP as additional data points, although the model was not constrained to pass through these points (Table 7). The derived equations accounted for $97.9,96.6$ and $95.8 \%$ of the total variance for the $\mathrm{F} 0, \mathrm{~F} 1$ and $\mathrm{F} 2$ diets respectively. $\mathrm{P} 1$, the rate of decline of $k_{f}$ with increasing MEI, was significantly decreased with the Fl diet as compared with the F0 or F2 diets. Consequently the calculated efficiencies of ME utilization were significantly elevated with the first increment of fishmeal, but dropped significantly with the F2 diet to values close to the efficiencies obtained with the basal diet. Efficiency values should be compared in the range of ME intakes which was common to any level of fishmeal, i.e. about $0 \cdot 6-0 \cdot 7 \mathrm{MJ} / \mathrm{d}$ per $\mathrm{kg} \mathrm{W}^{0.75}$. Table 7 included a larger range of intakes to give the general trends. In a similar manner to the results obtained with the linear relationships, the calculated ME requirements for maintenance (P2) were significantly higher with $F 1$ than with F0 diet, but decreased to intermediate values with F2. The standard error attached to the P3 value of the F1 diet was very large, mostly because of the negative energy retentions from one heifer. Exclusion of these data from the analysis changed the percentage of variance explained to $98.0 \%$ and resulted in the differences in 
$k_{f}$ between diets being no longer significant $(P<0.05)$. The difference in estimated maintenance requirements was also decreased (Table 7 ). Thus, the results suggest a tendency for the first increment of fishmeal to increase the efficiency of utilization of $\mathrm{ME}$ and the maintenance requirement of the animals but the statistical significance of these results appeared to relate to the data from one particular heifer.

\section{DISCUSSION}

Addition of the higher level of fishmeal to a fixed straw basal diet doubled total $\mathrm{N}$ intake. It increased the predicted (Agricultural Research Council, 1984) rumen degradable $\mathrm{N}$ (RDN) intake from 33 to $54 \mathrm{~g} / \mathrm{d}$ at the low plane of feeding and from 46 to $74 \mathrm{~g} / \mathrm{d}$ at the high plane of feeding. It also increased the undegradable $N$ intake from 4 to $33 \mathrm{~g} / \mathrm{d}$ at the low plane of feeding and from 6 to $46 \mathrm{~g} / \mathrm{d}$ at the high plane of feeding. These calculations assumed $\mathrm{N}$ degradability values of $0.5,0.8,0.8$ and 0.4 for straw (Smith, 1978), barley, sugarbeet pulp and fishmeal (Agricultural Research Council, 1980) respectively. In addition, the undegradable straw $\mathrm{N}$ was considered to be unavailable for absorption (Whitelaw et al. 1986).

As a response to these predicted changes, live-weight gains increased by $264 \mathrm{~g} / \mathrm{d}$ at the low plane of feeding and by $247 \mathrm{~g} / \mathrm{d}$ at the high plane of feeding. Live-weight gains increased with successive increments of fishmeal, although at the higher plane of feeding the response to the second increment of fishmeal was smaller than that to the first increment. In a previous experiment with equivalent levels of fishmeal supplementation to straw diets, live-weight gains of heifers fed at about 1.5 times maintenance were found to level off significantly at the higher level of fishmeal (Smith et al. 1980a).

These differences in live-weight gain are discussed in relation to diet digestibility and nutrient supply and to the partition of energy utilization.

\section{Diet digestibility and nutrient supply}

Addition of fishmeal to the basal diet enhanced DM, OM and GE digestibilities, mostly through an increase in ADF digestibility. The increased ADF digestion could have taken place in the large intestine, as shown previously (Ortigues et al. 1988). The elevated RDN supply to the rumen, as indicated by the higher rumen $\mathrm{NH}_{3}$ concentrations, could also have caused the elevated diet digestibility. By contrast the higher plane of feeding did not significantly modify the digestibility of the diets. The high level, however, only reached 1.9 times the maintenance requirements, compared with $1 \cdot 1$ times maintenance at the low level. Rate of passage of digesta through the tract may not have been sufficiently modified by such differences to induce changes in digestibility (Vermorel \& Bickel, 1980).

An interaction between the plane of feeding and the level of fishmeal supplementation was noted for OM digestibility. It paralleled a similar effect observed for plasma glucose concentration. The smaller response in digestibility to fishmeal between LF0 and LF1 on the one hand and between HF1 and HF2 on the other hand appeared to have been reflected in terms of live-weight gain at the high plane of feeding only. A limited energy supply relative to the $\mathrm{N}$ supply (Balch, 1967) could account for the tendency of the live-weight gains to plateau with the HF2 diet only.

$\mathrm{N}$ digestibility and balance were increased by fishmeal supplementation. In an experiment with similar straw diets, an elevated amino acid supply to the duodenum of steers supplemented with 110-120 g fishmeal $/ \mathrm{kg}$ dietary DM was observed (Ortigues et al. 1988). Other experiments, however, have reported a reduction in the increase in amino acid supply with successive increments of fishmeal added to silage-based diets (Cottrill et al. 1982; Gill \& Beever, 1982; Rooke \& Armstrong, 1987). Thus, the tendency for live-weight gains to plateau with the HF2 diet could also be due to a smaller increment in amino acid supply. 
Both the changes in total energy supply and in $\mathrm{N}$ supply could explain the responses in live-weight gain obtained. Whether total nutrient supply or the balance of nutrients supplied was responsible for the effects observed remains to be determined. In a previous experiment, supplementation of a straw diet with fishmeal at a level intermediate between $\mathrm{F} 1$ and $\mathrm{F} 2$ resulted in an increase in the proportion of $\mathrm{ME}$ originating from absorbed amino acids (Ortigues et al. 1988). Other experimental results would support the hypothesis that the balance of nutrients was a determining factor of the response to fishmeal. For example, it has been shown that growing beef bulls offered a concentrate diet containing $120 \mathrm{~g}$ crude protein $(\mathrm{N} \times 6.25 ; \mathrm{CP}) / \mathrm{kg} \mathrm{DM}$ had fatter carcasses than bulls offered diets containing 100 or $140 \mathrm{~g} \mathrm{CP} / \mathrm{kg} \mathrm{DM}$ and deposited less carcass protein than those offered the $140 \mathrm{~g} \mathrm{CP} / \mathrm{kg} \mathrm{DM}$ diet (Anderson et al. 1988).

\section{Partition of energy utilization}

The efficiency of ME utilization of the basal diet for growth was found to be comparable to that reported previously for straw-based diets (Wainman et al. 1975; Robb et al. 1980). However, while efficiency appeared to increase (not significantly) in response to the first increment of fishmeal, this increase was apparently lost with the second increment. Contradictions already exist in the literature with respect to the effect of dietary protein content on efficiency of ME utilization for growth. Negative or inconclusive results have been reported by Walker \& Norton (1971), Barry (1981) and Thomson et al. (1983), while positive relationships were found by Blaxter \& Boyne (1978) and Ribeiro et al. (1981). A more specific response to increased protein supply was shown by MacRae et al. (1985), who infused casein into the abomasum of mature sheep offered an autumn-harvested grass which increased efficiency values from 0.45 to 0.57 . Responses to protein supplementation in terms of energy utilization appear to depend on the physiological state of the animal (Ørskov et al. 1976) and on the balance of nutrients (Hartsook \& Hershberger, 1971; MacRae \& Lobley, 1986). Theoretical explanations of these results were presented in a simulation exercise by Black et al. (1987) which indicated the importance of considering the overall balance of nutrients available to the tissues. A similar exercise (Ortigues, 1987) was conducted using values from the present experiment and the assumptions collated by Gill et al. (1984). The main conclusions reached were that: (1) when ATP formed from acetate oxidation is used for protein deposition, rather than being dissipated, energetic efficiency is increased; (2) energetic efficiency decreases when acetate becomes limiting, as amino acids are then the main carbon and ATP sources; and (3) energetic efficiency is increased when the proportion of amino acids metabolized through gluconeogenesis is increased and when the proportion of glucose metabolized through the pentose phosphate pathway increases. In planning the experiment on this basis, it was hypothesized that an increase in efficiency would be measured with $F 1$ as a result of a reduction in wasteful oxidation of acetate and enhanced tissue deposition, while a lack of response might be obtained with the second increment of fishmeal if maximum protein deposition had been reached with the F1 diet or if acetate (energy) had become limiting or both. The present results do not unequivocally support this hypothesis because of the large between-animal variability. No explanation can be provided for the negative energy balance noted with one heifer on treatment LF1 but obviously such a variation in the data limits the conclusions drawn as to the effect of fishmeal supplementation on $k_{f}$.

The exponential nature of energy exchanges in animals offered different planes of nutrition has been shown (Blaxter \& Boyne, 1978; Cammell et al. 1986) and in the present experiment, the exponential model accounted for a greater proportion of the variance than the linear model. However, the relatively small range of MEI achieved with a straw-rich diet did not permit an adequate description of curvilinearity in the data, such that some of 
the parameters of the curves were calculated with a large error term (e.g. potential energy retention). Theoretically the exponential model has the advantage of permitting the efficiency of ME utilization to vary with change in growth rates and the associated changes in body composition, arising from modifying the level of intake (Geay \& Robelin, 1979). The present curvilinear relationships were defined using FHP values for animals stabilized on the F1 diet only. A more generalized use of the exponential model would require measurements of heat production in animals fully adapted to sub-maintenance levels of feeding.

In conclusion, no definite evidence could be obtained that the improvement in animal growth performance resulting from dietary supplementation with fishmeal was accompanied by changes in the efficiency of energy utilization. Further work is, therefore, required to measure both body composition and the supply of nutrients in order to achieve a full interpretation of the potential response to supplementation.

The excellent technical assistance of M. C. Spooner, M. J. Haines and Sarah Warrener and the statistical advice of M. S. Dhanoa are gratefully acknowledged. The senior author (I.O.) was in receipt of a scholarship from the European Economic Community, while the Institute for Grassland and Animal Production is an Agricultural and Food Research Council Institute and part of this work was commissioned by the Ministry of Agriculture, Fisheries and Food.

\section{REFERENCES}

Agricultural Research Council (1980). The Nutrient Requirements of Ruminant Livestock. Farnham Royal, Slough: Commonwealth Agricultural Bureaux.

Agricultural Research Council (1984). Report of the Protein Group of the Agricultural Research Council Working Party on the Nutrient Requirements of Ruminants. Farnham Royal, Slough: Commonwealth Agricultural Bureaux.

Anderson, P. T., Bergen, W. G., Merkel, R. A. \& Hawkins, D. R. (1988). The effects of dietary crude protein level on rate, efficiency and composition of gain of growing beef bulls. Journal of Animal Science 66, $1990-1996$.

Balch, C. C. (1967). Problems in predicting the value of non-protein nitrogen as a substitute for protein in rations for farm animals. World Review of Animal Production 3, 84-91.

Barry, T. N. (1981). Protein and metabolism in growing lambs fed on fresh ryegrass (Lolium perenne)-clover (Trifolium repens) pasture ad lib. 1. Protein and energy deposition in response to abomasum infusion of casein and methionine. British Journal of Nutrition 46, 52l-532.

Black, J. L., Gill, M., Thornley, J. H. M., Beever, D. E. \& Oldham, J. D. (1987). Simulation of the metabolism of absorbed energy yielding nutrients in young sheep; the efficiency of utilization of lipid and amino acid. Journal of Nutrition 117, 116-128

Blaxter, K. L. \& Boyne, A. W. (1978). The estimation of the nutritive value of feeds as energy sources for ruminants and the derivation of feeding systems. Journal of Agricultural Science, Cambridge 90, 47-68.

Brouwer, E. (1965). Report of sub-committee on constants and factors. In Energy Metabolism, European Association of Animal Production Publication no. 11 pp. 441-443 [K. L. Blaxter, editor]. London: Academic Press.

Cammell, S. B., Beever, D. E., Skelton, K. V. \& Spooner, M. C. (1981). The construction of open-circuit calorimeters for measuring gaseous exchange and heat production in sheep and young cattle. Laboratory Practice 30, 115-119.

Cammell, S. B., Thomson, D. J., Beever, D. E., Haines, M. J., Dhanoa, M. S. \& Spooner, M. C. (1986). The efficiency of energy utilization in growing cattle consuming fresh perennial ryegrass (Lolium perenne cv. Melle) or white clover (Trifolium repens cv. Blanca). British Journal of Nutrition 55, 669-680.

Cochran, W. G. \& Cox, G. M. (1957). Experimental Designs. New York: John Wiley \& Sons Inc.

Cottrill, B. R., Beever, D. E., Austin, A. R. \& Osbourn, D. F. (1982). The effect of protein and non-protein nitrogen supplements to maize silage on total amino acid supply in young cattle. British Journal of Nutrition $\mathbf{4 8}$ $527-541$

Geay, Y. \& Robelin, J. (1979). Variation of meat production capacity in cattle due to genotype and level of feeding: genotype-nutrition interaction. Livestock Production Science 6, 263-276.

Gill, M. \& Beever, D. E. (1982). The effect of protein supplementation on digestion and glucose metabolism in young cattle fed on silage. British Journal of Nutrition 48, 37-47.

Gill, M., Thornley, J. H. M., Black, J. L., Oldham, J. D. \& Beever, D. E. (1984). Simulation of the metabolism of absorbed energy-yielding nutrients in young sheep. British Journal of Nutrition 52, 621-649. 
Hartsook, E. W. \& Hershberger, T. V. (1971). Interactions of major nutrients in whole animal energy metabolism. Federation Proceedings 30, 1466-1473.

MacRae, J. C. \& Lobley, G. E. (1986). Interactions between energy and protein. In Control of Digestion and Metabolism in Ruminants, pp. 367-385 [L. Milligan, W. L. Grovum and A. Dobson, editors]. Englewood Cliffs: Prentice-Hall.

MacRae, J. C., Smith, J. S., Dewey, P. J. S., Brewer, A. C., Brown, D. S. \& Walker, A. (1985). The efficiency of utilization of metabolizable energy and apparent absorption of amino acids in sheep given spring-and autumnharvested dried grass. British Journal of Nutrition 54, 197-209.

Oldham, J. D. \& Smith, T. (1981). Protein-energy interrelationships for growing and for lactating cattle. In Protein Contribution of Feedstuffs for Ruminants: Application to Feed Formulation, pp. 103-130 [E. L. Miller, I. H. Pike and A. J. H. Van Es, editors]. London: Butterworths.

Ortigues, I. (1987). Nutrient supply, growth and calorimetric efficiency in heifers offered straw rich diets. $\mathrm{PhD}$ Thesis, University of Reading.

Ortigues, I., Smith, T., Oldham, J. D. \& Gill, M. (1988). The effects of fishmeal on growth and calorimetric efficiency in heifers offered straw-based diets. In Energy Metabolism, pp. 65-68 [Y. Van der Honing and W. H. Close, editors]. Wageningen: Centre for Agricultural Publishing and Documentation.

Ørskov, E. R., McDonald, I., Grubb, D. A. \& Pennie, K. (1976). The nutrition of the early weaned lamb. IV. Effects on growth rate, food utilization and body composition of changing from a low to a high protein diet. Journal of Agricultural Science, Cambridge 86, 411-423.

Ribeiro, J. M. C. R., MacRae, J. C. \& Webster, A. J. F. (1981). An attempt to explain differences in the nutritive value of spring- and autumn-harvested dried grass. Proceedings of the Nutrition Society 40, 12A.

Robb, J., Evans, P. J. \& Fisher, C. (1980). A study of the nutritional energetics of sodium hydroxide treated straw pellets in rations fed to growing lambs. In Energy Metabolism, pp. 63-67 [L. E. Mount, editor]. London: Butterworths.

Rooke, J. A. \& Armstrong, D. G. (1987). The digestion by cattle of silage and barley diets containing increasing quantities of fishmeal. Journal of Agricultural Science, Cambridge 109, 261-272.

Smith, T. (1978). The utilization of poor quality roughages by yearling dairy heifers. $\mathrm{PhD}$ Thesis, University of Reading.

Smith, T. (1979). The collection of faeces and urine from steers. Journal of the Science of Food and Agriculture $\mathbf{3 0}$, 215-217.

Smith, T., Broster, V. J. \& Hill, R. E. (1980a). A comparison of sources of supplementary nitrogen for young cattle receiving fibre rich diets. Journal of Agricultural Science, Cambridge 95, 687-695.

Smith, T., Broster, W. H. \& Siviter, J. W. (1980 $b$ ). An assessment of barley straw and oat hulls as energy sources for yearling cattle. Journal of Agricultural Science, Cambridge 95, 677-686.

Steen, R. W. J. (1985). Protein supplementation of silage-based diets for calves. Animal Production 41, 292-300.

Sutton, J. D. \& Johnson, V. W. (1969). Fermentation in the rumen of cows given rations containing hay and flaked maize or rolled barley in widely different proportions. Journal of Agricultural Science, Cambridge 73, 459-468.

Terry, R. A. \& Outen, G. E. (1973). The determination of cell-wall constituents in barley and maize. Chemistry and Industry 23, 1116-1117.

Thomson, D. J., Haines, M. J., Austin, A. R., Cammell, S. B., Beever, D. E., Dhanoa, M. S. \& Barnes, R. L. (1983). The voluntary intake, gain, tissue retention and efficiency of energy and protein utilization by Friesian steers of fresh perennial ryegrass and white clover. Animal Production 36, 501.

Van Soest, P. J. (1963). Use of detergents in the analysis of fibrous feeds. II. A rapid method for the determination of fibre and lignin. Journal of the Association of Official Agricultural Chemists 46, 829-835.

Vermorel, M. \& Bickel, H. (1980). Utilization of feed energy by growing ruminant animals. Annales de Zootechnie 29. $\left(\mathrm{n}^{\circ}\right.$ hors série) $127-143$.

Wainman, F. W., Smith, J. S. \& Dewey, P. J. S. (1975). The nutritive value for sheep of ruminant diet AA6, a complete cob diet containing 30\% barley straw. Journal of Agricultural Science, Cambridge 84, 109-111.

Walker, D. M. \& Norton, B. W. (1971). The utilization of the metabolizable energy of diets of different protein content by the milk-fed lamb. Journal of Agricultural Science, Cambridge 77, 363-369.

Whitelaw, F. G., Milne, J. S., Ørskov, E. R. \& Smith, J. S. (1986). The nitrogen and energy metabolism of lactating cows given abomasal infusions of casein. British Journal of Nutrition 55, 537-556. 